\title{
ANALISIS PROMOSI KESEHATAN BERDASARKAN OTTAWA CHARTER DI RS ONKOLOGI SURABAYA
}

\author{
HEALTH PROMOTION HOSPITAL BASED OTTAWA CHARTER IN \\ ONKOLOGI SURABAYA
}

\author{
Zelbi Windarini Tiraihati \\ Departemen Promosi Kesehatan dan Ilmu Perilaku \\ Fakultas Kesehatan Masyarakat, Universitas Airlangga, Surabaya \\ Email: zelbiwt@gmail.com
}

\begin{abstract}
Health promotion in hospitals have a purpose to increase public knowledge by conducting, counseling, education and training, and strengthening human resources to raise awareness, willingness and ability of people to live a clean and healthy. Health promotion in hospital can give the benefits to the hospital not only in physically sides or curative phase. The purpose of writing this article is to discuss the implementation of health promotion efforts based on Ottawa Charter at Surabaya Oncology hospital. The method used in this research is descriptive qualitative approach by direct observation and in depth interview. The implementation of health promotion on Onkologi Surabaya Hospital based on the five point of strategy health promotion in Ottawa Charter which are health public policy, supportive environment, reorient health services, personal skill, and community action has been appropriate. This is evidenced by the availability of media that support the implementation of health promotion, policy and the establishment the committee of PKRS. Also there are an effort to make community development as well as improving the skills of the individual in maintaining the health of the healthy individuals as well as improve the health of the sick patient. The implementation of health promotion in hospital hopefully can make the patient's family can help the patient not to infect the others especially to the family and their close friend. It also can make the patient increase their quality of living. Suggestion for Onkologi Hospital Surabaya based on the results of this study is to improve the evaluation system by conducting an evaluation in accordance with the rules that have been applied for the implementation of health promotion in the hospital can grow and run regularly.
\end{abstract}

Keywords: health promotion on hospital, Ottawa Charter

\begin{abstract}
Abstrak: Promosi kesehatan di rumah sakit bertujuan meningkatkan pengetahuan masyarakat dengan melakukan, penyuluhan, pendidikan dan pelatihan serta memperkuat sumber daya manusia untuk meningkatkan kesadaran, kemauan dan kemampuan masyarakat untuk hidup bersih dan sehat. Adanya promosi kesehatan di rumah sakit memberikan keuntungan bagi rumah sakit tidak hanya dalam bidang fisik atau kuratif. Tujuan dari penulisan artikel ini adalah untuk membahas implementasi upaya promosi kesehatan berdasarkan Ottawa Charter di rumah sakit Onkologi Surabaya. Metode yang digunakan dalam penelitian ini adalah deskriptif dengan pendekatan kualitatif dengan cara observasi langsung dan indepth interview. Penerapan promosi kesehatan di rumah sakit Onkologi Surabaya apabila dilihat berdasarkan lima poin strategi promosi kesehatan berdasarkan Ottawa Charter yaitu kebijakan berwawasan kesehatan, lingkungan yang mendukung, reorientasi pelayanan kesehatan, peningkatan keterampilan individu serta pemberdayaan masyarakat atau gerakan masyarakat telah sesuai. Hal tersebut dibuktikan dengan tersedianya media yang menunjang pelaksanaan promosi kesehatan, adanya kebijakan serta pembentukan panitia PKRS serta upaya bina suasana dan pemberdayaan masyarakat. Begitu juga upaya peningkatan keterampilan individu dalam mempertahankan derajat kesehatan bagi individu yang sehat serta meningkatkan derajat kesehatan bagi pasien yang sakit. Dengan terlaksananya promosi kesehatan di rumah sakit Onkologi Surabaya melingkupi lima aspek strategi promosi kesehatan Ottawa Charter maka dapat meningkatkan mutu pelayanan rumah sakit dan meningkatkan citra rumah sakit. Adanya promosi kesehatan di rumah sakit diharapkan mampu membuat keluarga pasien dapat membantu pasien atau keluarganya yang sakit agar tidak menularkan penyakitnya kepada orang lain, terutama kepada tetangga atau teman dekatnya. Saran bagi rumah sakit Onkologi Surabaya berdasarkan hasil penelitian ini adalah memperbaiki sistem evaluasi dengan melakukan evaluasi sesuai dengan peraturan yang telah diterapkan agar pelaksanaan promosi kesehatan di rumah sakit dapat berkembang dan berjalan dengan teratur.
\end{abstract}

Kata kunci: promosi kesehatan RS, Ottawa Charter 


\section{PENDAHULUAN}

Efektivitas pengobatan tidak hanya dipengaruhi oleh seberapa ampuh obat yang diberikan pada pasien. Hal tersebut dipengaruhi pula oleh pola pelayanan kesehatan. Pola pelayanan yang diberikan tidak hanya mengenai alur pelayanan kesehatan namun juga mencakup lingkungan pelayanan, kerja sama positif tenaga kesehatan dengan keluarga serta partisipasi dari masyarakat. Dalam melakukan pelayanan kesehatan diperlukan upaya promosi kesehatan. Promosi kesehatan menjadi hal yang penting dalam membangun paradigma sehat.

Promosi kesehatan merupakan upaya terkait memampukan, memberdayakan dan memandirikan masyarakat agar dapat meningkatkan taraf kesehatannya baik kesehatan diri sendiri maupun kesehatan lingkungan sekitar (Ottawa Charter, 1986). Menurut Green dan Kreuter, 2000 promosi kesehatan dapat tercapai dengan adanya kerja sama antara lembaga pendidikan serta lingkungan sekitar untuk meningkatkan kemandirian dan memberdayakan masyarakat dalam upaya meningkatkan derajat kesehatan masyarakat. Promosi kesehatan merupakan proses dalam memampukan individu maupun masyarakat untuk menyeimbangkan seluruh faktor yang berpengaruh pada kesehatannya sehingga dapat meningkatkan derajat kesehatan dirinya (WHO, 2007). Jadi kesimpulan dari beberapa pengertian promosi kesehatan diatas adalah proses memampukan, memberdayakan dan memandirikan masyarakat maupun individu dalam meningkatkan derajat kesehatannya.

Rumah sakit merupakan sebuah tempat pelayanan kesehatan yang sering diidentikkan dengan tingkat kuratif. Semakin modernnya zaman, rumah sakit berperan pula dalam memberikan pendidikan bagi orang-orang yang kurang mampu. Rumah sakit merupakan suatu institusi yang menyediakan layanan seperti rawat inap, rawat jalan serta pendidikan kesehatan secara perorangan (Kemenkes, UU no 44 tahun 2009). Rumah sakit tidak hanya diselenggarakan bagi upaya promosi dan preventif namun juga dapat menjadi sarana penyelenggaraan upaya kuratif dan rehabilitatif.

Pelaksanaan promosi kesehatan juga memiliki manfaat dalam menumbuhkan motivasi bagi pasien yang sedang melakukan perawatan baik rawat jalan maupun rawat inap. Pelaksanaan promosi kesehatan dapat mendorong seorang pasien termotivasi untuk kesembuhan dirinya serta meningkatkan mutu hidupnya. Hal tersebut juga dipengaruhi oleh keberadaan keluarga yang mendukung dalam pelaksanaan perawatan dan pengobatan. Berdasarkan manfaat tersebut promosi kesehatan di rumah sakit memiliki peranan penting dalam bidang peningkatan mutu pelayanan kesehatan serta kesehatan seseorang maupun masyarakat.

Hal tersebut menekankan pengertian bahwa promosi kesehatan merupakan proses yang memiliki tujuan untuk memungkinkan masyarakat maupun individu dalam meningkatkan maupun mempertahankan derajat kesehatannya. Tujuan dari promosi kesehatan di rumah sakit melalui pendekatan medik adalah untuk memastikan pasien maupun klien sehat terbebas dari penyakit serta kecacatan (secara medik) seperti penyakit infeksi, kanker serta jantung.

Nilai yang penting dari pendekatan medik upaya promosi kesehatan di rumah sakit adalah kepatuhan pasien terhadap prosedur pencegahan maupun kedokteran (pengobatan). Meskipun masih banyak orang yang berpikiran pelaksanaan upaya promosi kesehatan di rumah sakit dapat berdampak rugi pada rumah sakit baik dari segi tenaga, waktu, biaya serta memperkecil kunjungan namun sebenarnya promosi kesehatan di rumah sakit memberikan manfaat atau keuntungan bagi rumah sakit. Keuntungan-keuntungan yang diperoleh rumah sakit dengan melaksanakan upaya promosi kesehatan di rumah sakit adalah rumah sakit dapat meningkatkan mutu pelayanan rumah sakit.

Promosi kesehatan di rumah sakit dapat memberikan pelayanan psikososial yang merupakan hak pasien untuk meningkatkan derajat kesehatannya. Hal tersebut dapat membuat kunjungan pasien tidak hanya kunjungan bersifat pengobatan fisik. 
Promosi kesehatan di rumah sakit juga dapat meningkatkan citra rumah sakit. Promosi kesehatan rumah sakit dilakukan dengan pemberian informasi maupun perawatan lingkungan rumah sakit. Hal tersebut dapat memberikan kesan bahwa pelayanan rumah sakit merupakan pelayanan yang baik sehingga citra rumah sakit meningkat. Selain itu promosi kesehatan di rumah sakit juga bermanfaat dalam meningkatkan angka hunian rumah sakit. Adanya promosi kesehatan di rumah sakit dapat menyebabkan tingkat kesembuhan pasien menjadi lebih cepat. Hal ini berarti dengan adanya promosi kesehatan di rumah sakit dapat menyebabkan hari rawat pasien yang semakin pendek dan karena adanya turn over akibat hal tersebut dapat meningkatkan angka hunian rumah sakit.

Meskipun rumah sakit bergerak di bidang kuratif dan rehabilitatif namun rumah sakit wajib untuk memberikan promosi kesehatan. Perbedaan yang terdapat dalam dua aspek promosi kesehatan di bidang preventif dan kuratif adalah pada sasarannya. Apabila sasaran dari promosi kesehatan di bidang preventif adalah masyarakat maupun individu yang sehat maka sasaran dari promosi kesehatan di bidang kuratif adalah pasien yang bersangkutan beserta keluarganya dan juga pada petugas pelayanan kesehatan. Promosi kesehatan di rumah sakit memiliki tujuan sebagai upaya pencegahan kejadian keluarga yang terkena penyakit yang sama dengan pasien.

Promosi kesehatan memiliki tiga komponen yaitu pencegahan, perlindungan dan pendidikan kesehatan. Pencegahan melingkupi pencegahan terjadi nya suatu penyakit. Hal tersebut dapat dilakukan dengan menentukan kebijakan untuk melindungi masyarakat atau kelompok berisiko. Fungsi dari promosi kesehatan dalam bidang pencegahan memiliki lima aspek yaitu health promotion, specific protection, early diagnosis and prompt treatment, disability limitation dan rehabilitation. Kelima aspek tersebut digolongkan menjadi tiga pencegahan dalam pelayanan kesehatan yaitu pencegahan primer, sekunder dan tersier. Tiga upaya pencegahan ini merupakan komponen dari pelayanan kesehatan preventif. Meskipun bergerak di bidang preventif namun kelima aspek yang sering disebut dengan theory five levels of prevention ini juga diterapkan dalam promosi kesehatan rumah sakit.

Hal tersebut dilakukan dengan upaya rumah sakit dalam meningkatkan daya tahan tubuh terhadap masalah kesehatan serta memberikan perlindungan khusus untuk mencegah terjadi nya penularan pada klien sehat atau keluarga pasien terutama melakukan pencegahan penyebaran penyakit jika penyakit ini merupakan penyakit menular, mengobati dan menghentikan proses penyakit, menyembuhkan orang sakit serta mencegah terjadi nya komplikasi. Selain itu, rumah sakit juga berperan dalam mengatasi kecacatan yang telah terjadi agar tidak bertambah buruk. Hal tersebut juga berkaitan dengan upaya agar kecacatan yang telah dialami sesorang tidak berdampak lanjut pada psikologisnya.

Mengacu pada Undang-undang No 44 tahun 2009 yang telah ditetapkan oleh Kementerian Kesehatan terkait pelaksanaan rumah sakit maka penting bagi suatu rumah sakit untuk melaksanakan upaya kesehatan termasuk juga upaya promosi kesehatan. Hal tersebut sesuai dengan isi dari pasal 1 Undang-Undang No 44 tahun 2009 tentang pelayanan kesehatan paripurna di rumah sakit yang berupa upaya preventif, promotif, kuratif serta rehabilitatif. Promosi kesehatan memiliki penekanan bahwa promosi kesehatan tidak hanya tentang perubahan perilaku, melainkan juga perubahan lingkungan. Namun, promosi kesehatan merupakan program masyarakat yang menyeluruh.

Promosi kesehatan di rumah sakit sangat penting karena setiap orang memiliki hak mendapatkan informasi kesehatan untuk meningkatkan derajat kesehatannya serta agar dapat memecahkan dan mendapat pengobatan terhadap penyakit yang dideritanya. Menurut UU RI no 36 tahun 2009 pasal 7 setiap orang berhak mendapatkan informasi dan edukasi tentang kesehatan yang seimbang dan bertanggung jawab. Pengobatan yang efektif yang merupakan tujuan dari pengobatan rumah sakit dipengaruhi pula oleh pola pelayanan termasuk promosi kesehatan. 
Materi promosi kesehatan di rumah sakit juga beragam mulai dari pesan kesehatan yang terkait dengan pemeliharaan dan peningkatan kesehatan, pesan kesehatan yang terkait dengan pencegahan serangan penyakit yang meliputi gejala atau tandatanda penyakit, penyebab penyakit, cara penularan penyakit serta cara pencegahan penyakit. Tidak hanya itu promosi kesehatan di rumah sakit juga berisi pesan kesehatan yang terkait dengan proses penyembuhan dan pemulihan.

Tujuan dari penulisan artikel ini adalah untuk mengetahui penerapan konsep promosi kesehatan di rumah sakit Onkologi Surabaya serta kebijakan terkait pelaksanaan promosi kesehatan di rumah sakit Onkologi Surabaya. Artikel ini bertujuan untuk membahas implementasi lima sarana aksi strategi promosi kesehatan di rumah sakit berdasarkan Ottawa Charter.

\section{METODE}

Metode penelitian ini menggunakan pendekatan kualitatif melalui observasi dan indepth interview terhadap pihak rumah sakit. Metode penyajian data dari hasil penelitian ini adalah dengan metode deskriptif. Objek penelitian ini adalah ruangan atau tempat yang terdapat di rumah sakit Onkologi Surabaya. Penelitian ini dilakukan dalam kurun waktu kurang lebih satu bulan.

Penelitian ini menggunakan instrumen berupa instrumen penilaian observasi yang disusun berdasarkan Peraturan Menteri Kesehatan Republik Indonesia Nomor 004 Tahun 2012 Tentang Petunjuk Teknis Promosi Kesehatan Rumah Sakit. Observasi dilaksanakan lima kali dimulai pada tanggal 21 Maret 2016 hingga 27 April 2016. Observasi langsung dilakukan dengan cara melihat langsung pelaksanaan promosi kesehatan di lingkungan sekitar rumah sakit Onkologi Surabaya.

Pelaksanaan observasi ini didampingi oleh petugas rumah sakit Onkologi Surabaya. Wawancara atau indepth interview dilakukan untuk mendapatkan informasi terkait kebijakan maupun pelaksanaan promosi kesehatan di rumah sakit Onkologi Surabaya. Indepth interview dilakukan dengan pihak rumah sakit yaitu Kepala Departemen Bisnis serta salah satu staff Panitia Pelaksana PKRS di rumah sakit Onkologi Surabaya.

\section{HASIL PENELITIAN}

Upaya kesehatan merupakan suatu kegiatan untuk meningkatkan, memelihara dan mempertahankan kesehatan baik yang dilakukan secara mandiri maupun diselenggarakan oleh pemerintah. Upaya kesehatan di Indonesia dikelompokkan menjadi upaya kesehatan dalam bidang promotif, preventif, kuratif serta rehabilitatif. Aspek kuratif dan rehabilitatif sebagai cakupan dari upaya kesehatan bersifat pemeliharaan kesehatan sedangkan aspek promotif dan preventif merupakan cakupan dalam upaya kesehatan bersifat peningkatan kesehatan. Upaya kesehatan tersebut ditujukan agar mencapai sasaran pembangunan kesehatan. Upaya promosi kesehatan di rumah sakit merupakan bagian dari sektor kesehatan. Pelaksanaan promosi kesehatan di rumah sakit memiliki tujuan untuk mendukung upaya pembangunan kesehatan. Oleh karena itu upaya kesehatan dalam aspek promotif mengandung makna bahwa kesehatan individu maupun masyarakat harus selalu diupayakan sampai ke tingkat yang optimal.

Berdasarkan Permenkes RI Nomor 56 tahun 2014 tentang klasifikasi dan perizinan rumah sakit digolongkan ke dalam empat tipe berdasarkan pelayanannya. Rumah sakit dikelompokkan pada empat tipe rumah sakit yaitu: (1) Rumah sakit tipe A Rumah sakit tipe A yaitu rumah sakit yang memiliki pelayanan gawat darurat, medik spesialis dasar, medik spesialis penunjang, subspesialis serta spesialis gigi dan mulut. Rumah sakit tipe A diselenggarakan selama 24 jam sehari secara terus menerus. Rumah sakit tipe A memiliki sumber daya berupa tenaga medis, tenaga kefarmasian, tenaga keperawatan, tenaga kesehatan lain serta tenaga nonkesehatan. (2) Rumah sakit tipe B yaitu memiliki pelayanan medik, kefarmasian, keperawatan dan kebidanan, penunjang klinik, penunjang non klinik serta rawat inap. Rumah sakit tipe B dalam pelaksanaannya juga diselenggarakan dalam 
24 jam sehari. Rumah sakit tipe B memiliki sumber daya berupa tenaga medis, tenaga kefarmasian, tenaga keperawatan, tenaga kesehatan lain serta tenaga nonkesehatan. (3) Rumah sakit tipe $\mathrm{C}$ adalah rumah sakit yang menyediakan pelayanan medik, kefarmasian, keperawatan dan kebidanan, penunjang klinik, penunjang non klinik serta rawat inap. Rumah sakit tipe $\mathrm{C}$ juga diselenggarakan dalam 24 jam sehari. Rumah sakit tipe $\mathrm{C}$ memiliki pelayanan medik baik spesialis maupun pelayanan subspesialis. (4) Rumah sakit tipe D merupakan rumah sakit transisi. Rumah sakit ini hanya dapat memberikan pelayanan gawat darurat, medik umum, spesialis dasar dan spesialis penunjang. Rumah sakit tipe D diselenggarakan 24 jam sehari secara terusmenerus. Rumah sakit tipe D pratama adalah rumah sakit umum yang diselenggarakan di daerah tertinggal, perbatasan, atau kepulauan sesuai dengan peraturan dan ketentuan yang berlaku. Rumah sakit ini juga dapat didirikan di Kabupaten atau Kota dengan kriteria tertentu.

Berdasarkan Permenkes RI Nomor 56 tahun 2014 tentang klasifikasi dan perizinan rumah sakit, rumah sakit khusus adalah rumah sakit yang menangani masalah khusus seperti ibu dan anak, otak, kanker, bedah, ginjal dan lain-lain.

Rumah sakit Onkologi Surabaya beralamatkan di Araya Galaxy Bumi Permai Blok A2-7 Surabaya 60111. Telp/Email/Fax: (031)5914855/(031) 5914860. RSOS dapat dihubungi melalui email info@rsonkologi. com serta website www.rsonkologi.com. Rumah sakit Onkologi Surabaya tergolong pada rumah sakit tipe $\mathrm{C}$ dan khusus yang menyediakan pelayanan seputar penyakit kanker payudara, thyroid, kandungan, hemato, onkologi, pusat kemoterapi, bedah plastik rekonstruksi dan estetika serta konsultasi onkologi umum. Rumah sakit ini termasuk rumah sakit swasta.

Berdasarkan aspek-aspek yang terdapat dalam Peraturan Menteri Kesehatan Republik Indonesia No. 004 Tahun 2012 tentang Petunjuk Teknis Promosi Kesehatan Rumah Sakit dikelompokkan menjadi lima aspek sesuai dengan strategi dasar promosi kesehatan yaitu: Pemberdayaan masyarakat,
Bina Suasana, Advokasi, Kemitraan, dan Komunikasi.

Kelima aspek tersebut diberikan baik kepada pasien rawat inap, pasien rawat jalan, pengantar pasien maupun klien yang sehat. Petunjuk teknis promosi kesehatan di rumah sakit ini menyajikan secara terinci cara menerapkan strategi pemberdayaan, bina suasana, advokasi, kemitraan dan penggunaan media dalam rangka promosi kesehatan di rumah sakit.

Berdasarkan Ottawa Charter 1986 terdapat lima strategi promosi kesehatan yaitu Kebijakan berwawasan kesehatan (Health Public Policy), Lingkungan yang mendukung (Supportive environment), Reorientasi pelayanan kesehatan (Reorient health service), Keterampilan individu (Personal Skill) serta Gerakan masyarakat (Community action).

Kelima strategi tersebut bertujuan untuk menyeimbangkan penerapan promosi kesehatan sebagai upaya meningkatkan derajat kesehatan masyarakat dan mengurangi angka kesakitan. Strategi adalah suatu upaya atau langkah yang digunakan untuk mencapai suatu visi dan misi. Kaitan hasil dari penerapan promosi kesehatan di rumah sakit Onkologi Surabaya dengan lima strategi promosi kesehatan berdasarkan Ottawa Charter adalah:

Aspek pertama strategi promosi kesehatan berdasarkan Ottawa Charter adalah kebijakan berwawasan kesehatan (Health Public Policy). Kebijakan berwawasan kesehatan merujuk kepada kegiatan yang ditujukan untuk pembuat keputusan dan penentu kebijakan dalam mencapai suatu tujuan. Pencapaian suatu tujuan dilakukan melalui salah satu caranya dengan menentukan atau mengembangkan kebijakan-kebijakan berwawasan kesehatan. Berdasarkan hasil dari instrumen penilaian observasi yang dibuat mengacu pada Peraturan Menteri Kesehatan Republik Indonesia No. 004 Tahun 2012 tentang Petunjuk Teknis Promosi Kesehatan Rumah Sakit diketahui bahwa terdapat 110 pegawai tetap dan 10 pegawai kontrak. Kebijakan terkait promosi kesehatan dalam rumah sakit ini diatur sesuai kebijakan PKRS (Promosi Kesehatan Rumah Sakit). Rumah 
Sakit Onkologi Surabaya memiliki panduan kebijakan untuk PKRS serta pembentukan panitia PKRS menurut Keputusan Direktur No. 24/RSOS/SK_Dir/2015 tentang Pemberlakuan Kebijakan Promosi Kesehatan Rumah Sakit di Lingkungan Rumah Sakit Onkologi Surabaya. PKRS di rumah sakit Onkologi Surabaya sudah berlangsung selama 2 tahun.

Sesuai dengan tujuan kebijakan yang berwawasan kesehatan ini sasaran promosi kesehatan salah satunya adalah petugas kesehatan yang menjadi pengambil kebijakan atau pembuat keputusan baik institusi pemerintah atau swasta. Salah satu upaya rumah sakit Onkologi dalam hal ini adalah pembentukan tim PKRS yang memberlakukan kebijakan promosi kesehatan berdasarkan keputusan direktur rumah sakit. Kebijakan yang ditetapkan oleh tim PKRS dalam rumah sakit Onkologi Surabaya ini juga mengacu pada UndangUndang, Keputusan Menteri, serta pedoman promosi kesehatan di rumah sakit.

Pelaksanaan kebijakan ini diimbangi dengan dibentuknya panitia PKRS yang bertugas dalam upaya menjalankan penerapan PKRS. Rumah Sakit Onkologi Surabaya telah memiliki tenaga pengelola PKRS yaitu meliputi panitia PKRS dengan tugas sesuai dengan Keputusan Direktur No. 06/RSOS/SK_Dir/2014 tentang Panitia Promosi Kesehatan Rumah Sakit (PKRS) Rumah Sakit Onkologi Surabaya. Panitia PKRS yang dibentuk oleh Rumah Sakit Onkologi Surabaya terdiri dari beberapa bagian. Bagian-bagian yang ada dalam panitia PKRS di Onkologi Surabaya memiliki tugas masing-masing.

Salah satu tujuan rumah sakit Onkologi Surabaya telah sesuai dalam melakukan promosi kesehatan yaitu dengan menerapkan kebijakan berwawasan kesehatan. Hal ini sesuai dengan strategi pertama promosi kesehatan berdasarkan Ottawa Charter.

Aspek kedua adalah menciptakan lingkungan yang mendukung (Supportive environment). Lingkungan yang kondusif dan nyaman merupakan salah satu aspek yang mendukung penerapan promosi kesehatan di rumah sakit. Berdasarkan Permenkes RI Nomor 56 tahun 2014 tentang klasifikasi dan perizinan rumah sakit salah satu syarat tata bangunan dan lingkungan rumah sakit adalah perancangan pemanfaatan tata ruang dalam bangunan yang efektif sesuai dengan fungsi-fungsi pelayanan. Penataan lingkungan rumah sakit Onkologi Surabaya sudah sangat baik. Hal ini terbukti dengan pemanfaatan media dengan benar, tidak berlebihan namun sesuai dengan kebutuhan. Pendukung dalam pelaksanaan PKRS seperti yang tercantum, dalam Peraturan Menteri Kesehatan Republik Indonesia No. 004 Tahun 2012 Tentang Petunjuk Teknis Promosi Kesehatan Rumah Sakit adalah berupa metode dan media. Penggunaan media dalam menunjang aspek komunikasi pada penerapan promosi kesehatan di rumah sakit Onkologi Surabaya ini juga telah dilaksanakan dengan baik.

Media-media yang digunakan rumah sakit Onkologi Surabaya sebagai penunjang upaya promosi kesehatan berdasarkan instrumen observasi yaitu: Ruang Pendaftaran, media yang digunakan untuk menunjang upaya promosi kesehatan di ruang pendaftaran rumah sakit Onkologi Surabaya adalah petugas kesehatan baik dokter maupun perawat, televisi yang berisi profil rumah sakit. Ruang pendaftaran rumah sakit Onkologi Surabaya juga menyediakan media leaflet dan poster untuk memberikan informasi terkait upaya preventif, promotif, kuratif dan rehabilitative suatu penyakit. Ruang Rawat Jalan, media yang digunakan untuk menunjang upaya promosi kesehatan di rumah sakit Onkologi Surabaya di ruang rawat jalan meliputi pelayanan konseling pasien, tersedianya media komunikasi kesehatan seperti leaflet dan flip chart serta adanya himbauan PHBS berupa poster lengkap dengan sabun dan wastafel.

Begitu juga dengan ruang tunggu, media yang digunakan sebagai penunjang upaya promosi kesehatan di ruang tunggu rumah sakit Onkologi Surabaya adalah poster, X-banner, leaflet dan televisi yang berisikan informasi terkait penyakit kanker. Tidak hanya itu, di setiap ruang tunggu atau mini counter disediakan wastafel dan juga sabun sebagai sarana cuci tangan beserta poster tata cara cuci tangan yang benar. Selanjutnya ruang inap, media yang digunakan sebagai penunjang upaya promosi kesehatan di ruang inap adalah konseling di 
tempat tidur, poster serta leaflet yang bisa dibawa pulang keluarga untuk membantu proses penyembuhan penyakit yang diderita pasien. Ruang Pembayaran, media yang digunakan di ruang pembayaran untuk menunjang upaya promosi kesehatan adalah leaflet dan buku-buku seputar kesehatan. Ruang pembayaran juga menyediakan wastafel serta sabun untuk cuci tangan serta poster yang berisikan teknik desinfeksi yang efektif.

Ruang Penunjang Medik, media di dalam ruang penunjang medik yang digunakan untuk media promosi kesehatan adalah tersedianya leaflet. Kamar Mandi, media yang terdapat di kamar mandi sebagai penunjang promosi kesehatan adalah dengan adanya poster berisi imbauan dan tata cara cuci tangan yang benar. Selain itu, terdapat tempat sampah serta imbauan membuang sampah pada tempatnya. Tempat Parkir, media di tempat parkir yang digunakan sebagai sarana promosi kesehatan berupa papan dengan isi pesan bahwa rumah sakit Onkologi Surabaya merupakan Kawasan Tanpa Rokok.

Kantin Rumah Sakit, media yang digunakan sebagai sarana promosi kesehatan yang terdapat di kantin rumah sakit berupa poster imbauan PHBS serta karena letaknya yang berada dekat dengan ruang tungu memudahkan pengunjung untuk melihat televisi yang digunakan untuk sarana penyampaian pesan promosi kesehatan. Terakhir adalah tempat ibadah, media yang digunakan di tempat ibadah sebagai sarana promosi kesehatan berupa imbauan dilarang merokok berupa poster dan juga tempat sampah sebagai imbauan membuang sampah pada tempatnya.

Sepuluh tempat pelaksanaan promosi kesehatan diatas ditetapkan sebagai tempattempat untuk melakukan promosi kesehatan berdasarkan Peraturan Menteri Kesehatan Republik Indonesia Nomor 004 Tahun 2012 Tentang Petunjuk Teknis Promosi Kesehatan Rumah Sakit. Materi dari promosi kesehatan di rumah sakit menggunakan media yang ditampilkan pada pasien maupun keluarga pasien memiliki tiga pesan yaitu: (1) Pesan kesehatan tentang peningkatan dan pemeliharaan dan peningkatan kesehatan seperti olahraga rutin, tidak merokok dan minum alkohol, makanan gizi seimbang serta cuci tangan pakai sabun. (2) Pesan kesehatan tentang upaya pencegahan dan penularan penyakit. (3) Pesan kesehatan tentang upaya penyembuhan dan pemulihan penyakit. Berdasarkan Undang-undang No. 29 Tahun 2004 pasal 52 tentang Praktik kedokteran dijelaskan bahwa hak-hak yang dimiliki pasien meliputi mendapatkan penjelasan secara lengkap tentang tindakan medis. Hal ini merupakan salah satu upaya promosi kesehatan agar pasien mengetahui perkembangan dari perawatan maupun pengobatannya. Secara tidak langsung hal tersebut dapat meningkatkan kepercayaan diri pasien dalam upaya meningkatkan mutu hidup dirinya.

Rumah sakit Onkologi juga melakukan kajian tentang kebutuhan kegiatan promosi kesehatan yang dibutuhkan oleh pasien maupun keluarga pasien. Hal ini juga tidak lepas dari kebijakan direktur rumah sakit yang tidak memperbolehkan menempelkan poster atau gambar terlalu banyak di dinding. Rumah sakit membuat leaflet atau flip chart untuk mempermudah pasien mendapat informasi tanpa harus menempel gambar di dinding. Terkait upaya mempermudah akses informasi pasien maupun keluarga upaya promosi kesehatan di rumah sakit Onkologi juga menerapkan penulisan catatan rekam medis pasien. Hal tersebut sesuai dengan hak pasien yang tercantum pada Undang-undang No. 29 tahun 2004 pasal 52 tentang Praktik Kedokteran bahwa pasien berhak atas informasi rekam medis. Hal tersebut juga didukung dengan menjadi kan lingkungan rumah sakit Kawasan Tanpa Rokok. Faktor-faktor di luar lingkungan rumah sakit juga memiliki peran penting dalam upaya promosi kesehatan berjalan dengan baik untuk memberikan pelayanan yang memuaskan bagi pasien maupun keluarga pasien.

Lingkungan sosial yang baik juga mendukung upaya pelayanan kesehatan di rumah sakit onkologi ini. Pelayanan yang tepat dan cepat menjadi komitmen rumah sakit. Tidak hanya itu rumah sakit juga memiliki prinsip pasien adalah keluarga. Rumah sakit Onkologi Surabaya juga 
menampilkan taman hidup yang dapat menghilangkan kesan kering, sakit dan kurang ramah pada rumah sakit tersebut.

Dalam menunjang lingkungan yang mendukung bagi proses promosi kesehatan di rumah sakit maka rumah sakit Onkologi juga melakukan berbagai kemitraan yang menunjang promosi kesehatan di rumah sakit. Salah satu kemitraan yang dilakukan oleh rumah sakit Onkologi adalah rumah sakit Onkologi Surabaya bekerja sama dengan KPI untuk melaksanakan program deteksi dini di desa-desa yang ada di Tuban dan Jombang. Disana rumah sakit Onkologi bertindak sebagai narasumber namun juga melibatkan ibu PKK dalam melakukan health education terkait penyakit kanker.

Upaya rumah sakit Onkologi dalam menciptakan lingkungan yang mendukung promosi kesehatan sesuai dengan standar petunjuk teknis promosi kesehatan rumah sakit yaitu dengan memelihara sarana dan prasarana kesehatan lingkungan rumah sakit serta menjadi kan rumah sakit Onkologi sebagai kawasan tanpa rokok (KTR). Selain itu bentuk kemitraan yang di jalan oleh rumah sakit Onkologi juga sesuai dengan substandard promosi kesehatan dengan cara rumah sakit telah mengidentifikasi mitra atau partner yang memiliki manfaat potensial dan saling menguntungkan dalam rangka memperkuat dan memperluas jangkauan promosi kesehatan rumah sakit Onkologi. Hal ini dibuktikan dengan rumah sakit Onkologi memiliki kemitraan dengan sektor lain dari dunia bisnis atau swasta di luar lingkup kesehatan. Rumah Sakit Onkologi dalam pelaksanaannya tidak melakukan mitra dengan BPJS. Hal tersebut tidak sesuai dengan peraturan terkait pelaksanaan BPJS karena seharusnya setiap rumah sakit melakukan kemitraan dengan BPJS. Hal tersebut menjadi salah satu kekurangan rumah sakit Onkologi Surabaya dalam hal kemitraan.

Aspek selanjutnya adalah reorientasi pelayanan kesehatan (Reorient health service). Reorientasi pelayanan kesehatan adalah suatu kegiatan yang melibatkan masyarakat. Upaya melibatkan masyarakat langsung untuk memelihara dan meningkatkan taraf kesehatannya sendiri melibatkan masyarakat dalam upaya promosi kesehatan juga penting. Pelayanan kesehatan berbasis masyarakat dapat dilakukan misal dengan membentuk lembaga swadaya masyarakat yang peduli dengan kesehatan masyarakat. Upaya promosi kesehatan akan berjalan dengan baik apabila dua komponen promosi kesehatan yaitu penyedia pelayanan kesehatan dan pihak yang membutuhkan pelayanan kesehatan saling bertanggungjawab dan memiliki persamaan persepsi terkait tugas dan wewenang serta hak kesehatan. Rumah Sakit Onkologi Surabaya telah melaksanakan pelayanan kesehatan dengan melibatkan masyarakat.

Hal ini tentunya berhubungan dengan masyarakat khususnya masyarakat yang peduli dengan kanker karena pada dasarnya rumah sakit Onkologi Surabaya ini merupakan rumah sakit yang khusus menangani beberapa penyakit kanker. Rumah Sakit Onkologi juga memiliki agenda yang melibatkan masyarakat dengan melakukan peringatan breast cancer di 13 kota seluruh Indonesia.

Selain berupaya dalam melakukan pendekatan lewat maupun melibatkan masyarakat rumah sakit Onkologi kurang dalam melakukan menata ulang pelayanan kesehatan. Hal tersebut dapat dilihat sebagai evaluasi bahwa kurangnya evaluasi rumah sakit khususnya bidang PKRS terkait penata ulangan pelayanan kesehatan.

Aspek selanjutnya dari Ottawa Charter terkait promosi kesehatan adalah keterampilan individu (Personal Skill). Keterampilan individu adalah upaya peningkatan pengetahuan dan kemampuan individu dalam masyarakat untuk memelihara kesehatan, mengenal gejala awal penyakit, penyebab suatu penyakit, pengobatan serta perawatan kesehatan. Dalam mewujudkan kesehatan masyarakat secara keseluruhan, keterampilan individu mutlak diperlukan. Dengan harapan semakin banyak individu yang terampil dalam memelihara diri sendiri dalam bidang kesehatan. Keterampilan individu sangatlah diharapkan dalam mewujudkan keadaan masyarakat yang sehat. Rumah sakit Onkologi Surabaya telah melakukan promosi kesehatan dengan upaya meningkatkan keterampilan individu. Hal tersebut dilakukan dengan cara penyediaan 
informasi baik berupa media seperti poster dan leaflet namun juga melalui konseling atau konsultasi. Pendukung dalam pelaksanaan PKRS seperti yang tercantum, dalam Peraturan Menteri Kesehatan Republik Indonesia No. 004 Tahun 2012 Tentang Petunjuk Teknis Promosi Kesehatan Rumah Sakit adalah berupa metode dan media. Penggunaan media dalam menunjang aspek komunikasi pada penerapan promosi kesehatan di rumah sakit Onkologi Surabaya ini juga telah dilaksanakan dengan baik.

Sasaran konseling adalah klien, baik klien sakit maupun keluarga klien. Konseling dilakukan untuk memberikan pengertian serta menumbuhkan konsep diri dan kepercayaan diri sendiri. Selain itu rumah sakit ini juga memberikan konsultasi untuk pasien maupun keluarga pasien untuk meningkatkan kesadaran tentang kesehatan dan meningkatkan derajat kesehatan. Terdapat imbauan cuci tangan lengkap dengan penyediaan wastafel dan sabun dalam menerapkan promosi kesehatan tentang cuci tangan serta penyediaan tempat sampah di setiap ruangan rumah sakit yang digolongkan menjadi tempat sampah medis dan non medis.

Upaya konseling yang dilakukan oleh rumah sakit Onkologi Surabaya terhadap klien sakit atau pasien adalah dengan menyambut klien dengan hangat, menanyakan tentang keadaan mereka, serta melakukan tindak lanjut konseling. Tidak hanya itu rumah sakit Onkologi Surabaya juga melakukan konseling pada keluarga klien dengan cara menjelaskan bagaimana mencegah terjadi nya masalah yang sama (penyakit yang sama). Rumah sakit Onkologi Surabaya memberikan informasi secara jelas tentang kondisi pasien sehingga pasien dan keluarga paham tentang pengobatan dan perawatan yang sesuai dengan kondisi pasien. Selain itu hak pasien berdasarkan Undang-undang No. 29 tahun 2004 pasal 52 tentang Praktik kedokteran adalah terkait meminta pendapat dokter lainnya ataupun pendapat bidang lain di rumah sakit. Hal tersebut sejalan dengan konseling yang dilakukan sebagai upaya promosi kesehatan di rumah sakit Onkologi.
Peningkatan keterampilan tidak hanya diberikan pada pasien dan keluarga pasien namun juga pada petugas atau tenaga kesehatan di rumah sakit Onkologi Surabaya. Peningkatan keterampilan yang dilakukan oleh rumah sakit Onkologi Surabaya adalah dengan memberikan pengetahuan tentang cara memelihara kesehatan, mengenali gejala awal penyakit kanker, serta meningkatkan kemampuan pasien dalam meningkatkan kesehatan dirinya sendiri maupun keluarga. Upaya peningkatan keterampilan juga dilakukan dengan bekerja sama dengan berbagai aspek dalam memberikan health education.

Upaya-upaya yang telah dilakukan oleh rumah sakit Onkologi telah sesuai dengan tujuan khusus upaya promosi kesehatan dalam mengembangkan perilaku sehat dan bersih atau perilaku kesehatan pasien dan keluarga. Hal tersebut bermanfaat untuk mempercepat pemulihan dan kesembuhan pasien rawat inap maupun rawat jalan di rumah sakit Onkologi. Upaya-upaya tersebut juga bermanfaat untuk mencegah terjadi nya kekambuhan penyakit serta terjadi nya penularan kepada orang lain terutama keluarga.

Aspek terakhir adalah gerakan masyarakat (Community action). Gerakan masyarakat adalah suatu upaya dalam wujud pemberdayaan masyarakat yang memiliki tujuan meningkatkan derajat kesehatan masyarakat sendiri, meningkatkan pengetahuan masyarakat dengan melakukan penyuluhan, pendidikan dan pelatihan serta memperkuat sumber daya manusia untuk meningkatkan kesadaran, kemauan dan kemampuan masyarakat untuk hidup bersih dan sehat.

Rumah sakit Onkologi Surabaya melakukan promosi kesehatan berbasis kesehatan masyarakat salah satunya dengan cara membentuk komunitas survivor dari penderita kanker sehingga mereka dapat berbagi pengalaman dan cara pencegahan serta tahap pengobatan. Adanya komunitas breast cancer yang dibentuk oleh rumah sakit Onkologi Surabaya ini bertujuan agar para penderita kanker yang tengah berjuang hidup dapat mengupayakan peningkatan kesehatan mereka sendiri. 
Dalam upaya meningkatkan derajat kesehatan masyarakat melalui cara ini rumah sakit Onkologi memiliki pandangan klien dihargai sebagai individu yang berpengetahuan, memiliki keterampilan serta dapat berkontribusi dalam upaya kesehatan.

Upaya pemberdayaan masyarakat yang dilakukan rumah sakit Onkologi Surabaya tidak hanya dilakukan di dalam rumah sakit saja namun juga di luar rumah sakit. Hal ini berupa penyuluhan atau health education di hotel, kantor maupun institusi pendidikan. Penyuluhan yang dilakukan biasanya dilakukan dalam rangka peringatan hari kanker.

Isi dari penyuluhan tersebut adalah tentang cara mengenali gejala awal kanker, alur pemeriksaan, tata cara pengobatan hingga perawatan bahkan juga cara penularan dan pencegahan penyakit. Tidak hanya terbatas pada penyuluhan namun rumah sakit Onkologi Surabaya juga melakukan konseling pada pasien maupun keluarga pasien terkait penyakit yang mereka derita.

Berdasarkan tujuan dari adanya pemberdayaan masyarakat rumah sakit Onkologi telah menyesuaikan upaya pemberdayaan masyarakat sesuai dengan substandar promosi kesehatan masyarakat yaitu Rumah Sakit Onkologi memberikan informasi yang jelas serta lengkap terkait dengan keadaan pasien tentang penyakitnya atau keadaannya, rumah sakit Onkologi menyediakan akses yang cukup kepada masyarakat untuk memperoleh informasi tentang masalah kesehatan khususnya kanker serta rumah sakit Onkologi tidak hanya melakukan pemberdayaan atau promosi kesehatan di dalam ruangan saja namun juga di luar ruangan.

\section{KESIMPULAN}

Rumah Sakit Onkologi Surabaya telah menerapkan upaya promosi kesehatan yang baik sesuai dengan strategi promosi kesehatan berdasarkan dengan Ottawa Charter. Promosi kesehatan yang diterapkan dalam rumah sakit Onkologi ini telah mencakup lima aspek yaitu kebijakan berwawasan kesehatan (Health Public Policy), lingkungan yang mendukung (Supportive environment), reorientasi pelayanan kesehatan (Reorient health service), keterampilan individu (Personal Skill), serta gerakan masyarakat (Community action).

Kelima aspek strategi promosi kesehatan tersebut juga ditunjang dengan pembentukan panitia PKRS (Promosi Kesehatan Rumah Sakit) yang mengacu pada peraturan tentang petunjuk teknis pelaksanaan PKRS. Sesuai dengan kelima aspek strategi yang telah dipenuhi rumah sakit Onkologi Surabaya berdasarkan Ottawa Charter tujuan khusus dari pelaksanaan promosi kesehatan di rumah sakit Onkologi telah terpenuhi yaitu dalam mengembangkan perilaku kesehatan, mengembangkan perilaku pemanfaatan pada pasien, membantu mempercepat proses penyembuhan pasien, serta menghindarkan keluarga dalam penularan penyakit (mencegah kesakitan).

Dengan terlaksananya promosi kesehatan di rumah sakit Onkologi Surabaya melingkupi lima aspek strategi promosi kesehatan Ottawa Charter maka dapat meningkatkan mutu pelayanan rumah sakit dan meningkatkan citra rumah sakit. Dengan adanya promosi kesehatan di rumah sakit diharapkan mampu membuat keluarga pasien dapat membantu pasien atau keluarganya yang sakit agar tidak menularkan penyakitnya kepada orang lain, terutama kepada tetangga atau teman dekatnya.

Kekurangan rumah sakit Onkologi pada pelaksanaan PKRS adalah tidak melakukan kemitraan dengan BPJS. Terkait proses evaluasi pada rumah sakit Onkologi Surabaya menunjukkan kekurangan akibat kurangnya proses evaluasi pada proses pelaksanaan promosi kesehatan di rumah sakit serta dalam hal menata ulang tim promosi kesehatan yang ada. Saran bagi rumah sakit Onkologi Surabaya terkait pelaksanaan promosi kesehatan di rumah sakit adalah melakukan evaluasi sesuai dengan tujuan yang ingin dicapai oleh rumah sakit dalam hal memberikan pelayanan yang menjadi salah satu aspek pelaksanaan promosi kesehatan. 


\section{DAFTAR PUSTAKA}

Green, L.W., \& Kreuter, M.W. 2000.Commentary on The Emerging Guide to Community Preventive Services from a Health Promotion Perspective. American Journal of Preventive Medicine, 18 (1), 7-9.

Indonesia, D.P.R.R. 2009. Undang-Undang Nomor 44 Tahun 2009 Tentang Rumah Sakit. Jakarta: Sekretariat Negara Republik Indonesia.

Indonesia, R. 2009.Undang-Undang Nomor 36 Tahun 2009 tentang Kesehatan. Jakarta: Republik Indonesia.

Kemenkes RI Pusat Promosi Kesehatan. 2010.Standar promosi Kesehatan di Rumah Sakit (PKRS). (Online) tersedia pada http://www.pdpersco.id/website/ persi/data/pkrs.pdf. Diakses 20 Maret 2016.

Kemenkes. 2012.Pusat Promosi Kesehatan Mahler, H., Epp, J., Franklin, W., \&
Kickbush, I. 1986. Ottawa Charter for Health Promotion. Health Promotion International, 1(4), 405.

Maulana, Heri dkk. 2009. Promosi Kesehatan. Jakarta: Penerbit Buku Kedokteran EGC.

Peraturan Menteri Kesehatan Republik Indonesia Nomor 004 tahun 2012.

Pusat Promosi Kesehatan Kementerian Republik Indonesia. Standar Promosi Kesehatan di rumah Sakit (PKRS). 2010.

Undang-Undang No. 29 tahun 2004 tentang Praktik Kedokteran Pasal 52

World Health Organization. 2007. Cancer control: knowledge into action: WHO guide for effective programmes (Vol. 2). World Health Organization.

WHO, Pan American Health Organization. 1996. Health Promotion: An Anthology. Pan American Sanitary Bureau, Regional Office of the WHO. Washington, D.C. 20037, USA. 